\title{
The effectiveness of practicum-based worksheet based on salt hydrolysis material viewed from the aspect of laboratory skills and interpersonal intelligence learners
}

Elsa Ari Astuti, Sri Wardani, Sri Kadarwati, Kasmui

Department of Chemistry, Universitas Negeri Semarang, Indonesia

\begin{tabular}{|c|c|}
\hline Article Info & ABSTRACT \\
\hline Article history: & \multirow{7}{*}{$\begin{array}{l}\text { This study aims to determine the effectiveness of a practicum worksheet } \\
\text { (LKPPD) based on guided inquiry and the response of learners as users. } \\
\text { The effectiveness of LKPPD is seen from aspects of laboratory skills and } \\
\text { students' interpersonal intelligence on hydrolysis material. This type of } \\
\text { research is qualitative and quantitative. Data collected by interview, } \\
\text { observation, and questionnaire. The results showed that LKPPD that has } \\
\text { been developed is effective because } 76 \% \text { of students have laboratory skills } \\
\text { with very high category and } 96.5 \% \text { of students have interpersonal } \\
\text { intelligence with a minimum category high. In addition, this LKPPD } \\
\text { received a positive response from learners as users with a percentage score } \\
\text { of } 77.9 \% \text {. }\end{array}$} \\
\hline Received Jan 20, 2019 & \\
\hline Revised Mar 8, 2019 & \\
\hline Accepted Sep 13, 2019 & \\
\hline Keywords: & \\
\hline & \\
\hline $\begin{array}{l}\text { Interpersonal intelligence } \\
\text { Laboratory skills }\end{array}$ & \\
\hline
\end{tabular}

Copyright $@ 2019$ Institute of Advanced Engineering and Science. All rights reserved.

\section{Corresponding Author:}

Sri Wardani,

Chemistry Education Study Program,

Semarang State University,

Sekaran Road, Gunung Pati Township, Semarang County, Central Java 50229, Indonesia.

Email: menuksriwardani@gmail.com

\section{INTRODUCTION}

Learning chemistry as part of the education component of Indonesia has educational objectives to provide knowledge and insight, develop the attitude of learners, and hone certain skills and skills [1]. Skill in question is one of the skills of students in the laboratory, such as skills to prepare tools and materials, perform experimental procedures, and read the metering tool carefully. This is because the chemistry contains knowledge systematically arranged, organized and in the form of a collection of observational data or experiments [2].

Experiments in lab activities conducted in the laboratory will encourage students to have laboratory skills [3, 4]. In the meantime, practicum conducted in groups will affect the ability of learners to organize teams, work together, and maintain group unity. This ability is the intelligence in connecting and understanding other people outside of themselves called interpersonal intelligence [5, 6].

Interpersonal intelligence can be developed through practicum activities [7], which consists of collecting basic knowledge by equating one's own opinion with the group, the stage of information analysis, and the high level of thinking and reasoning. These stages guide the individual to see the various phenomena from the other person's point of view, in order to understand how they perceive and feel, so as to establish good abilities in organizing teams, establishing cooperation or maintaining unity within the practicum group $[8,9]$.

Practicum is a suitable method for learning chemistry [10]. This is because learning chemistry is not enough just to memorize facts and concepts that already exist, but also required to find and find the facts and concepts through experiment [1]. Thus, the lab is an important part of improving the success of the teaching 
and learning process of chemistry $[4,11]$ supported by learning facilities and infrastructure. One means of supporting the success of chemistry learning is the practicum worksheet of learners (LKPPD).

The availability of facilities and infrastructures supporting chemistry learning relatively the same in SMA Kebon Dalem Semarang and SMA Sint Louis Semarang revealed from the interview with the chemistry teacher of each school. The existing LKPPD is only a brief explanation directly, so it does not help learners in finding their own knowledge. In addition, it is known that students of class X and XI MIPA less active in chemistry learning process using lecture method. This affects the value of daily test of learners. A total of more than $50 \%$ of learners have not reached the Minimum Exhaustiveness Criteria (KKM) especially on Hydrolysis material. The same is found [12,13] suggesting that the learners' learning outcomes on hydrolysis matter were still quite low. The possibility cause is the low understanding of the learner to connect between one concept to another [14]. In addition, the lack of practicum activities as a method that strongly supports the learning process to make it easier for learners to understand the material even though the students showed a higher enthusiasm when the lab activities took place.

The results of the interviews also show that the hydrolysis materials that have been taught have been using teaching materials in the form of a package book and a practical manual sheet. Lack of teaching materials used are still textual, so that learners are less able to find their own knowledge that was originally considered abstract. This will confuse learners, so that the learning indicators that should be in line with the 2013 curriculum requirements are less than the maximum achieved by the learners. The 2013 curriculum requires learners to be more active in learning [9].

Learning on hydrolysis materials using LKPPD needs to apply one of the learning models to help learners discover their own knowledge while also helping learners develop their skills in the laboratory. The learning model is guided inquiry. Guided inquiry learning model is a learning based on the view of contructive which requires learners to be able to find their own knowledge [8]. Stages of this learning model include the identification and determination of the problem (orientation), making the hypothesis followed by designing experiments (exploration), experimenting and making conclusions and communicating them [15].

LKPPD based inquiry on guided hydrolysis material is feasible to be used to support the teachinglearning process by presenting guided inquiry synthesis in learning. However, this guided inquiry-based LKPPD is not yet known for its effectiveness in terms of laboratory skills and students 'interpersonal intelligence, so the formulation of the problem in this research is how the effectiveness of workbooks based on inquiry is guided on hydrolysis material seen from the aspect of laboratory excellence and students' interpersonal intelligence.

\section{RESEARCH METHOD}

The research was conducted at SMA Sint Louis Semarang on February 12 - March 2, 2018. The type of this research is qualitative-quantitative. Determination of research sample is done by purposive sampling technique. The sample in this research is class XI MIPA1 as many as 29 students.

Data collection techniques were conducted by interview, observation, and questionnaires. Interview method was conducted to get initial data related to chemistry learning and learning support facilities in school using interview sheet instrument, observation method using instrument observation sheet was done to obtain data of laboratory skill and interpersonal intelligence of learners, and questionnaire method was done to obtain data of participant response educated on the effectiveness of LKPPD using questionnaire instruments.

Qualitative data in the form of data of interview result related to chemistry learning and instructional supporting facilities in school analyzed descriptively. Quantitative data are laboratory skill data, interpersonal intelligence, student's answer data in LKPPD, and learners' responses are analyzed by calculating the mean score and determining criteria at certain class intervals. Indicators of a success in this study LKPPD declared effective if the proportion of at least 22 of 29 learners had laboratory skills and interpersonal intelligence with a minimum category high, and understanding the concept to reach the value of KKM (minimum completeness criteria) (more than $75 \%$ of the number of learners).

\section{RESULTS AND ANALYSIS}

The identification that has been done shows that SMA Sint Louis Semarang has a chemistry laboratory with complete facilities and equipment such as chairs and practicum tables, demonstration tables, tool cabinets, material cabinets, sinks, measuring cups, glasses, reaction tubes and shelves, (tackle, stative, and clamp), dropper dropper, measuring pipette, drop plate, incubus burner, clamp, pumpkin, funnel, stirrer, erlenmeyer flask, mortar, spray bottle, watch glass, separating funnel, balance sheet, paper litmus, universal indicator, thermometer, foot three and wire gauze base, reaction tube brush, and periodic table of elements. The materials available at Sint Louis Semarang SMA chemistry laboratory are also sufficient, including 
acetic acid, sodium hydroxide, sodium chloride, hydrochloric acid, ammonium sulfate, ammonium nitrate, sodium bicarbonate, and sodium benzoate solutions.

Identification of problems in SMA Sint Louis Semarang provided information that the use of laboratory in the learning process is less than optimal, which is indicated by the small frequency of the practicum during the learning process takes place even though the laboratory facilities are adequate for the implementation of the lab. Practicum in SMA Sint Louis Semarang rarely done with the reason of preparation and implementation takes a long time. The rarity of the frequency of the lab makes the learners less skilled in the laboratory. Usually teachers use lecture methods and group discussions in the learning process of chemistry. If the practicum is implemented, the learner is only required to follow the work procedure on the laboratory manual in LKPPD which is integrated with the pesesian LKPPD. This LKPPD directly presents tools, materials, and work steps from the practicum that will be done. Learners are asked to practice according to the practice manual already in LKPPD. This causes the learners lack the ability to design their own lab work to be done. As a result learners less than the maximum in finding their own knowledge [16].

LKPPD guided inquiry-based hydrolysis material to measure laboratory skills and interpersonal intelligence of learners has been developed that is specifically designed for learning activities with chronologically arranged methods. LKPPD contains brief information about the application of materials in everyday life, tool planning, materials, and work procedures, observation, data analysis, conclusions, and discussion activities.

Data analysis in LKPPD is presented in the form of questions aimed at assisting learners to process and analyze data that has been collected either from the results of collecting data/experiments or the results of observing and gathering information. Data processing will increase the breadth and depth to the information processing that is looking for solutions the problems to be solved [17]. The data that is processed and analyzed becomes the basis for the next activity that is processing information to find the relation of one information with other information, find the pattern of the information linkage, even find the new concept/knowledge.

The LKPPD is structured in accordance with the guided inquiry instruction syntax combined with laboratory skill indicators and interpersonal intelligence so as to hone laboratory skills and interpersonal skills of learners. This can happen because learning with guided inquiry makes learners more active in learning by inviting learners to discover their own concepts or theories they are studying through their own inquiry and analysis based on experiments done [18].

LKPPD design results have been feasible to be used for learning and can support and provide benefits especially during the chemistry learning process takes place. LKPPD based inquiry is guided on hydrolysis material consisting of cover page, subcover page, content page, end page, and back cover page. In this study, LKPPD that has been feasible will be known effectiveness seen from aspects of laboratory skills and intelligence interpersonal learners.

The effectiveness of guided inquiry self-guided working hydraulic worksheets developed can be indicated by observation of laboratory skills and students 'interpersonal intelligence, and the students' understanding of the concept (cognitive) of LKPPD in the chemistry of hydrolysis material learning. The result of observation of laboratory skill of learners on the implementation of practicum activity 1 and the guided inquiry assisted LKPPD II is shown by Table 1.

Table 1. The recapitulation of laboratory skill observation result

\begin{tabular}{ccc}
\hline \multirow{2}{*}{ Criteria } & \multicolumn{2}{c}{ Number of Students $(\%)$} \\
& Practice I & Practice II \\
\hline Very high & 62 & 90 \\
High & 38 & 10 \\
Low & 0 & 0 \\
Very low & 0 & 0 \\
\hline
\end{tabular}

In practice I and II, observation data of laboratory skills of learners consists of six aspects. Data on recapitulation of laboratory skill observation of each aspect in one class on a large scale trial is shown in Figure 1. 


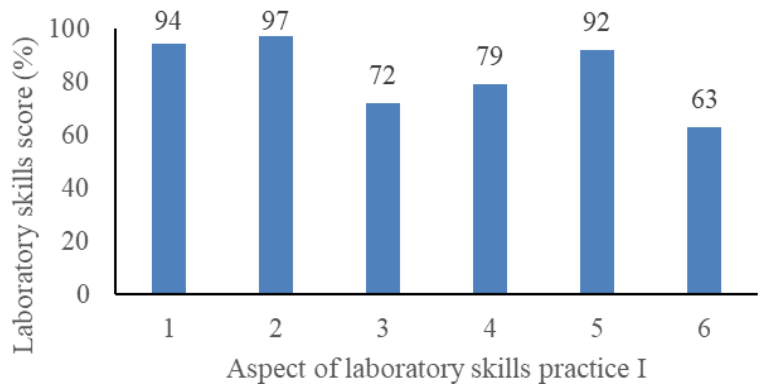

(a)

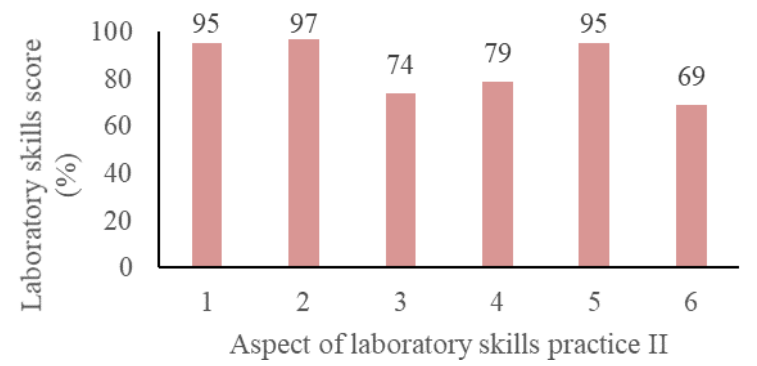

(b)

Figure 1. Observation results laboratory skills students (a) Practicum I, (b) Practicum II

\section{Caption Figure 1(a):}

1. Prepare the tools needed for the assay of the properties and $\mathrm{pH}$ of the salt

2. Preparing the materials used for the assay of the properties and $\mathrm{pH}$ of the salt

3. Transfer the saline solution tested its nature with dropper drops into the drop plate

4. Observe the color change on litmus paper when testing the properties of the saline solution

5. Cleaning the tools used after the lab is complete

6. Cleaning the place (table) after the lab is complete.

Caption Figure 1(b):

1. Prepare the tools needed for the determination of salt $\mathrm{pH}$ from acid and base mixtures

2. Prepare the ingredients used for the determination of salt $\mathrm{pH}$ from acid and base mixtures

3. Read the volume scale on the measuring cup when taking the acid solution and the base solution to be reacted with a certain volume.

4. Using the universal indicator when measuring the $\mathrm{pH}$ of the solution

5. Cleaning the tools used after the lab is complete

6. Cleaning the place (table) after the lab is finished.

Based on the data in Figure 1(a) it can be seen that the aspect laboratory skills of preparing the materials, preparing the tools, and cleaning the practicum tool in practice I scored $94 \%, 97 \%$ and $92 \%$ respectively with very high category. This can happen because in LKPPD developed there is a stage of designing experiments (guidance inquiry third syntax) that asks learners to design the tools and materials needed to carry out the lab with the guidance of the teacher, so that learners can prepare the tools and materials appropriately as well as cleaning tools that have been used for practice [19]. In addition, these three aspects are part of technical lab, so easy to do by learners.

The next highest-order aspect of Practicum I is the aspect of observing the color change on the litmus paper and removing the solution with a pipette. In LKPPD developed there is a stage to design the tool up to the practical work step. The process of designing these tools and work steps allows learners to think and analyze related functions and the right tools to carry out experimental work steps, so that learners know the workings of the tools they will use to carry out investigative activities. This is done of course with the guidance of teachers. In addition, LKPPD used in the beginning also presents a table of some equipment that is often used in chemical labs (including the name of the tool, images, equipped with the function of the tool), so as to help learners know the function of laboratory equipment. Aspects with the last sequence on the first practicum to clean the place or the practicum table. LKPPD used by students to ask students to do practicum from the beginning stage, this, until the end of the practicum in the form of cleaning the practice site. When the practicum process is implemented, the table used is not dirty, so only a few learners who clean the practice site.

In Practicum II, based on the data in Figure 1(b) it can be seen that the three aspects that have the highest lab skills categories are preparing tools, preparing materials, and cleaning practice tools with the same scores of $95 \%, 97 \%$, and $95 \%$ very high). This is because the LKPPD terdadapt stage designing experiments on LKPPD developed the stage of preparing tools and materials used for the lab with the guidance of teachers. Learners can prepare tools and materials for the practicum properly and clean the practicum after the experiment completed. Aspects with the next highest sequence on practicum II are aspects of using the universal indicator when measuring the $\mathrm{pH}$ of the solution and reading the volume scale on the measuring cup. Aspects with the last sequence on practice II is the aspect of cleaning the place or the practicum table. This result is almost the same as laboratory skill in practice I. 
Based on the data in Table 1 shows that the result of observation of laboratory skill of learners at lab I is improving on practice of II, because in LKPPD developed there is stage designing experiment covering designing tools, materials, and step work practice, stage of the practicum implementation that has been designed, and stage of data analysis with teacher guidance that can make learners do practicum with appropriate step of work so that can train skill learners work in laboratory. In the second lab, the students have had the experience of practicum from I. Based on Table 1 it can be seen that as many as $100 \%$ of students in both lab and lab 2 have lab skills with a minimum category high. This means more than $75 \%$ of the total number of practitioners reach a minimum high.

In addition to observation of laboratory skills of learners, observation of interpersonal intelligence of learners is also done at the time of the implementation of practicum activities I and practicum II using LKPPD that has been developed. The result of observation of interpersonal intelligence of learners is shown by Table 2 .

Table 2. Recapitulation of observation result of interpersonal intelligence of learners

\begin{tabular}{ccc}
\hline \multirow{2}{*}{ Criteria } & \multicolumn{2}{c}{ Number of student (\%) } \\
& Practice I & Practice II \\
\hline Very high & 14 & 14 \\
High & 79 & 86 \\
Low & 7 & 0 \\
Very low & 0 & 0 \\
\hline
\end{tabular}

Based on the data Table 2 it can be seen that as many as 93\% of learners have interpersonal intelligence with a minimum category high on practice I (assay properties and salt $\mathrm{pH}$ ) and $100 \%$ learners have interpersonal intelligence with a minimum category high on practice II (determination of $\mathrm{pH}$ salt of mixture acid-base). This means that more than $75 \%$ of the total number of practitioners reach a minimum high.

There are six aspects of the assessment to reveal the interpersonal intelligence of learners on practicum I and II. The six aspects are collaboration at the lab, responsible for practicum, listening to others during the discussion, asking questions during the discussion, answering questions during the discussion, and providing assistance in answering questions during the discussion. Data on recapitulation observation of interpersonal intelligence of learners of each aspect in one class on a large scale trial is shown in Figure 2.

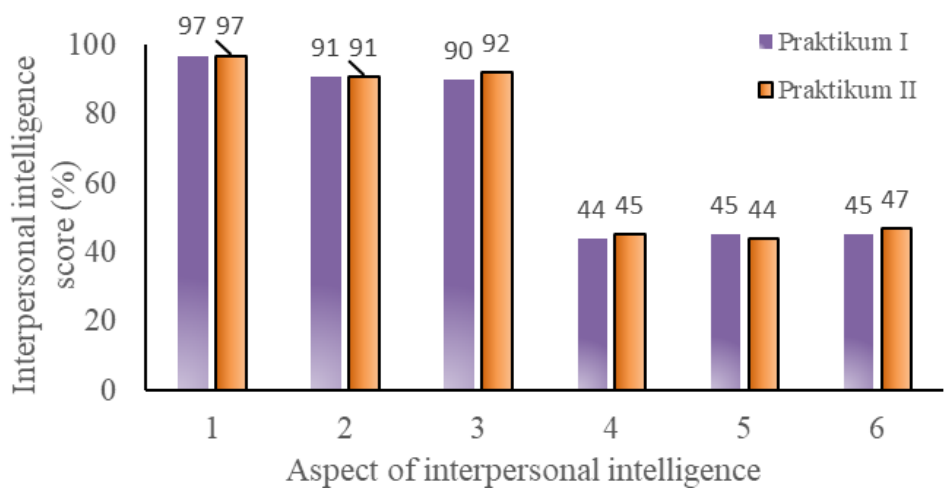

Figure 2. Observation results interpersonal intelligence learners

Information:

1. Cooperate during lab work

2. Responsible in doing step work from beginning to end practice implementation

3. Listening to others when there are groups that present the results of their experiments and when the discussion (question and answer)

4. Ask questions during discussion

5. Answering questions during discussion

6. Provide assistance in answering questions during discussion. 
Based on Figure 2 it can be seen that the result of observation of interpersonal intelligence of learners with the third highest sequence both at labum I and II is the aspect of cooperating when practicum, responsible during practicum, and listen to others during discussion. This happens because in LKPPD developed there is a phase of communicating the results of the experiment in the form of discussion activities (sixth guided inquiry syntax) where at that stage learners are given the opportunity to discuss with friends in one group to present the results of experiments that have been obtained, listening to friends who are presented his experimental results with teacher guidance which is an indicator of interpersonal intelligence. LKPPD-assisted practice can develop interpersonal intelligence [20].

Aspects in the next sequence are aspects of asking questions during discussions, answering questions during discussions, and providing answer assistance in answering questions during discussion. These three aspects fall into the low category. This can happen because of lack of space in LKPPD for learners to pour questions to be asked. In addition, the existence of custom or culture that is formed by itself in the classroom that is only a few learners who are actively asking and answering during the discussion although the LKPPD has been given the opportunity to conduct discussion activities that include question and answer activities.

The results of understanding the concepts of learners in the realm of cognitive. Cognitive domain is one of the goals of national education that is oriented to the ability to think that includes intellectual ability or emphasize the understanding of the theories learned learners [21] so that the concept of understanding (cognitive) must exist in every learning as a result of learners aspect cognitive. The results of understanding the concepts of learners are obtained from the value of practicum when students do LKPPD. Recapitulation of understanding results of learners' concepts is presented in Table 3.

Table 3. Recapitulation of understanding result of learners concept

\begin{tabular}{ccc}
\hline \multirow{2}{*}{ Criteria } & \multicolumn{2}{c}{ Number of student (\%) } \\
& Practice I & Practice II \\
\hline KKM is reached $(\geq 75)$ & 100 & 100 \\
KKM is not reached $(<75)$ & 0 & 0 \\
\hline
\end{tabular}

Based on Table 3 it can be seen that $100 \%$ of learners both on labs I and II have an understanding of the concept with categories reaching KKM or it can be revealed that the value obtained by all learners on large-scale trial reached $\geq 75$.

Student's response data is used to determine students' responses to LKPPD developed on a wider scale. The response of learners is important to know because it is one of the requirements LKPPD developed can be used for learning. LKPPD can be used for learning if the LKPPD gets a positive response. Recapitulation of learners' responses to large-scale trials is presented in Table 4.

Table 4. Recapitulation of test results of learners

\begin{tabular}{ccc}
\hline Interval $(\%)$ & Criteria & Number of student $(\%)$ \\
\hline $85 \geq 100$ & Very good & 24 \\
$70 \geq 84$ & Good & 62 \\
$55 \geq 69$ & Good enough & 10 \\
$40 \geq 54$ & Not good & 0 \\
$0 \geq 39$ & Bad & 0 \\
\hline
\end{tabular}

Based on data from Table 4 it can be seen that as many as $90 \%$ responded to the use of LKP developed with the category of at least good and $10 \%$ responded with good enough category, so it can be said most learners give positive response to LKPPD.

Based on the observation of laboratory skills, the students' understanding of the concept data and the learners' responses to the guided inquiry-based LKPPD that has been developed, the developed LKPPD is said to be effective for measuring laboratory skills and students' interpersonal intelligence.

\section{CONCLUSION}

Based on the results of this study it can be concluded that $76 \%$ of learners have very high laboratory skills and $96.5 \%$ of students have interpersonal intelligence with a minimum of high category so that the guided inquiry practice sheet is declared effective to measure laboratory skills and students' interpersonal intelligence on the material hydrolysis, and get a positive response from learners as users with a percentage score of $77.9 \%$.

The effectiveness of practicum-based worksheet based on salt hydrolysis material viewed ... (Elsa Ari Astuti) 


\section{REFERENCES}

[1] D.M. Pratiwi, S. Saputro and A. C. S. Nugroho, "Development of guided inquiry-based practicum worksheets guided on the buffer solution highlights senior high school grade IPA XI (in Bahasa)," Jurnal Pendidikan Kimia (JPK), vol. 4, pp. 32-37, 2015.

[2] D. Handayani, "development of science learning practicum instructions to improve practical skills of middle school students (in Bahasa)," Artikel E-Journal, 2016.

[3] P. P. J. Brown, "Process-oriented guided-inquiry learning in an introductory anatomy and physiology course with a diverse student population," Adv Physiol Educ, vol. 34, pp. 150-155, 2010.

[4] S. N. Baeti, A. Binadja and E. Susilaningsih, "SETS vision-based practicum learning to improve laboratory skills and competency mastery (in Bahasa)," Jurnal Inovasi Pendidikan Kimia, vol. 8, pp.1260-1270, 2014.

[5] A, Wahyuni, Sulaiman and Mahmud, H.R., "Relationship of students' interpersonal intelligence with verbal bullying behavior at SD N 40 Banda Aceh (in Bahasa)," Jurnal Pesona Dasar, vol. 3. pp. 33-42, 2016.

[6] S. Handayani, Sumarno, Dwi Ampuni "Efforts to improve interpersonal intelligence in early childhood through outdoor learning in TK Pembina, Rembang Regency (in Bahasa)," SEUNEUBOK LADA: Jurnal ilmu-ilmu Sejarah, Sosial, Budaya dan Kependidikan, vol. 6, no. 1, pp. 63-73, 2019.

[7] S. Wardani, "Weakness analysis of student explanations in relation to work culture and development of interintrapersonal intelligence in electrometry lectures (in Bahasa)," Jurnal Inovasi Pendidikan Kimia, vol. 8, pp. 1219-1229, 2014.

[8] Sri Wardani, Santi Setiawan and Kasmadi Imam Supardi, "The effect of guided inquiry learning on understanding concepts and oral activities on the subject material for reduction and oxidation reactions (in Bahasa)," Jurnal Inovasi Pendidikan Kimia, vol. 10, pp. 1743-1750, 2016.

[9] Novia Ayu Sekar Pertiwi, "Implementation of physics learning by engaging intrapersonal and interpersonal intelligence (in Bahasa)," Science Education Journal, vol. 2, no. 1, pp. 37-53, 2018.

[10] Solehudin, "Development of salt hydrolysis learning kit with guided inquiry learning model to improve science process skills and scientific attitudes (in Bahasa)," Syntax Literate, Jurnal Ilmiah Indonesia, vol. 2, no. 8, pp. 112-123, 2017.

[11] U. F. Arifin, S. Hadisaputro and E. Susilaningsih, "Development of an integrated student practicum worksheet guided inquiry for science process skills (in Bahasa)," Chemistry in Education, vol. 4, pp. 54-60, 2015.

[12] H. Sa'idah, M. Kusasi and A. Hamid, "Improving learning activities and outcomes using the collaborative model of discovery learning and number head together (NHT) on salt hydrolysis material in 12th High School Banjarmasin (in Bahasa)," Journal of Chemistry and Education, vol. 1, pp. 52-57, 2017.

[13] Dina, A. Setiabudi and Nahadi, "Problem based learning to improve the argumentation skills of high school students on the concept of salt hydrolysis (in Bahasa)," Jurnal Pendidikan Matematika dan Sains, vol. 3, pp. 133-142, 2015.

[14] Y. Muslimah, "Improving student activities and learning outcomes on salt hydrolysis material through the students teams achievement division (STAD) model (in Bahasa)," Jurnal Vidya Karya, vol. 27, pp. 25-36, 2012.

[15] Sukma, L. Komariyah and M. Syam, "The effect of guided inquiry learning model and motivation on student physics learning (in Bahasa)," Saintifika, vol. 18, pp. 59-63, 2016.

[16] A. A. I. Sari, "Developing curiosity in mathematics learning through guided discovery of settings TPS (in Bahasa)," Prosiding Seminar Matematika dan Pendidikan Matematika, vol. 27, pp. 373-382, 2016.

[17] M. A. K. Budiyanto, L. Waluyo and A. Mokhtar, "The implementation of scientific approach to learning in elementary education Malang (in Bahasa)," Proceeding Biology Education Conference, vol. 13, pp. 46-51, 2016.

[18] Aeni A. Q., Saptorini and Supardi K. I., "The effectiveness of guided inquiry-based practicum learning on student lab skills (in Bahasa)," Chemistry in Education, vol. 6, no. 1, pp. 8-13, 2017.

[19] A. L. Nuritasari, S. Wardani and Supartono, "Development of student worksheets for stoichiometry inquiry laboratory activities (in Bahasa)," Journal of Innovative Science Education, vol. 5, pp. 54-62, 2016.

[20] M. Saufi and M. Royani, "Develop interpersonal intelligence and student self-confidence through the effectiveness of the PBL learning model (in Bahasa)," Jurnal Pendidikan Matematika, vol. 2, pp. 106-115, 2016.

[21] I. Nurbudiyani, "The implementation of cognitive, affective, and psychomotor domain measures in social sciences class III SD Muhammadiyah Palangkaraya (in Bahasa)," Pedagogik Jurnal Pendidikan, vol. 8, pp. 12-20, 2013.

\section{BIOGRAPHIES OF AUTHORS}

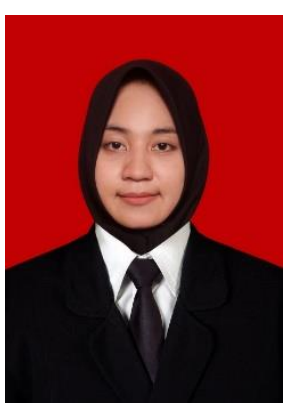

Elsa Ari Astuti born in Grobogan, January 19 ${ }^{\text {th }}$ 1996. In 2010, she comlpeted first school education at 1 Tawangharjo Elementary School, continuing her Junior High School in 1 Tawangharjo Junior High School and her Senior High School at 1 Purwodadi Senior High School. In 2018, she completed first degree at Semarang State University and now she continuing her Second degree at Semarang State University. Her Organization Experience is as Staff of Himamia at Semarang State University in 2015-2016.

Email: elsa.ari44@ @mail.com

J. Edu. \& Learn. Vol. 13, No. 4, November 2019: 502 - 509 


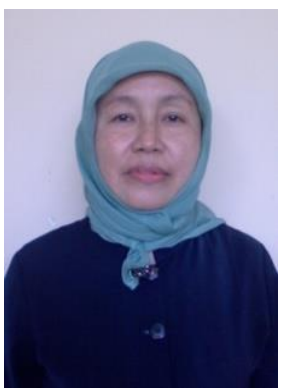

Sri Wardani born in Pontianak, November $8^{\text {th }}$ 1957. She worked as a Lecturer in Universitas Negeri Semarang

Email: menuksriwardani@gmail.com

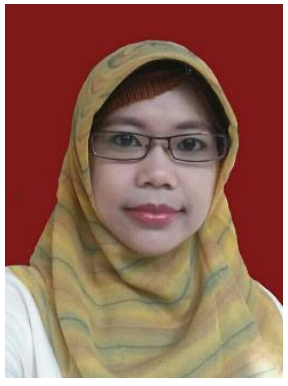

Sri Kadarwati born in Demak, November $14^{\text {th }} 1981$. She worked as a Lecturer in Universitas Negeri Semarang

Email: sri_kadarwati@yahoo.co.id

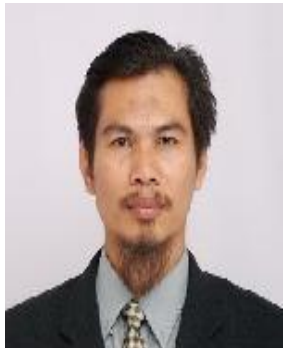

Kasmui born in Brebes, Desember $7^{\text {th }} 1970$. He worked as a Lecturer in Universitas Negeri Semarang

Email:kasmui@mail.unnes.ac.id 